\title{
DEFINISI PATEN SERTA SISTEM YANG DITERAPKAN DIINDONESIA DALAM MEMBERIKAN HAK PATEN PADA INVENTOR
}

\author{
Erina Oktarini \\ 155100027 \\ Fakultas Komputer, 448757166 \\ erinaoktarini.student@umitra.ac.id
}

\begin{abstract}
Paten adalah hak khusus yang diberikan oleh Negara kepada penemu atas hasil penemuannya di bidang teknologi, yang untuk selama waktu tertentu melaksanakan sendiri Invensinya tersebut atau memberikan persetujuannya kepada pihak lain untuk melaksanakannya. Pengertian paten sendiri dimaksukan dalam Undang-Undang yang terletak pada pasal 1 ayat 1 UU tentang paten.

Inventor adalah seseorang yang secara sendiri atau beberapa orang yang secara bersama-sama melaksanakan ide yang dituangkan kedalam kegiatan yang menghasilkan invensi ( Temuan ).

Penerapan pada Hak Paten sendiri diindonesia dinilai dari sistem inventor pertamayang mendaftarkan produk mereka untuk dipatenkan.

Kata Kunci : Paten, dan Inventor

\section{A. INTRODUCTION}

Paten adalah hak khusus yang diberikan oleh Negara kepada penemu atas hasil penemuannya di bidang teknologi, yang untuk selama

waktu tertentu melaksanakan sendiri Invensinya tersebut atau memberikan persetujuannya kepada pihak lain untuk melaksanakannya. Pengertian paten sendiri dimaksukan
\end{abstract}




\begin{abstract}
dalam Undang-Undang yang terletak pada pasal 1 ayat $1 \mathrm{UU}$ tentang paten.

Kata paten, berasal dari bahasa inggris patent, yang awalnya berasal dari kata patere yang berarti membuka diri (untuk pemeriksaan publik), dan juga berasal dari istilah letters patent, yaitu surat keputusan yang dikeluarkan kerajaan yang memberikan hak eksklusif kepada individu dan pelaku bisnis tertentu. Dari definisi kata paten itu sendiri, konsep paten mendorong inventor untuk membuka pengetahuan demi kemajuan masyarakat dan sebagai gantinya, inventor mendapat hak eksklusif selama periode tertentu. Mengingat pemberian paten tidak mengatur siapa yang harus melakukan invensi yang dipatenkan, sistem paten tidak dianggap sebagai hak monopoli.
\end{abstract}

Saat ini terdapat beberapa perjanjian internasional yang mengatur tentang hukum paten. Antara lain, WTO Perjanjian TRIPs yang diikuti hampir semua negara.

Pemberian hak paten bersifat teritorial, yaitu, mengikat hanya dalam lokasi tertentu. Dengan demikian, untuk mendapatkan perlindungan paten di beberapa negara atau wilayah, seseorang harus mengajukan aplikasi paten di masing-masing negara atau wilayah tersebut.

Secara umum, ada tiga kategori besar mengenai subjek yang dapat dipatenkan: proses, mesin, dan barang yang diproduksi dan digunakan. Proses mencakup algoritme, metode bisnis, sebagian besar perangkat lunak (software), teknik medis, teknik olahraga dan semacamnya. Mesin mencakup alat dan aparatus.

Barang yang diproduksi mencakup perangkat mekanik, perangkat elektronik dan komposisi materi seperti 
kimia, obatobatan, DNA, RNA, dan sebagainya. Khusus Sel punca embrionik manusia (human embryonic stem atau hES) tidak bisa dipatenkan di Uni Eropa.

Ada 2 macam sistem yang dipakai pada pendaftaran paten

, yaitu :

1. Sistem First to File, sistem ini dalam pendaftaran paten dilakukan bagi mereka yang mendaftarkan pertama atas invensi baru sesuai dengan persyaratan.

2. Sistem First to Invent, adalah suatu sistem yang memberikan hak paten bagi mereka yang menemukan inovasi pertama kali sesuai dengan persyaratan yang telah ditentukan.

Dalam melakukan Hak paten , Indonesia sendiri menerapkan pada sistem yang pertam yaitu sistem First to File , dimana inventor yang pertama kali mendaftrakan suatu produk mereka berhak mendaftakan hak paten dengan syarat dan ketentuan berlaku.

\section{B. CONCLUSION}

Paten adalah hak khusus yang diberikan oleh Negara kepada penemu atas hasil penemuannya di bidang teknologi, yang untuk selama waktu tertentu melaksanakan sendiri Invensinya tersebut atau memberikan persetujuannya kepada pihak lain untuk melaksanakannya. Pengertian paten sendiri dimaksukan dalam Undang-Undang yang terletak pada pasal 1 ayat $1 \mathrm{UU}$ tentang paten.

Inventor adalah seseorang yang secara sendiri atau beberapa orang yang secara bersama-sama melaksanakan ide yang dituangkan kedalam kegiatan yang menghasilkan invensi ( Temuan ).

\section{Penerapan pada Hak Paten} sendiri diindonesia dinilai dari sistem inventor pertamayang mendaftarkan produk mereka untuk dipatenkan. 
C. ACKNOWLEDGEMENT

University Of Indonesia

University Of Mitra Indonesia

Telkom University

University Of Mellbourne

Saitama University

D. REFERENCE(Based ISo 690 )

A. S. Putra And O. M. Febriani, "Knowledge Management Online Application In Pdam Lampung Province," In Prosiding International Conference On Information Technology And Business (Icitb), 2018, Pp. 181-187.

[2] A. S. Putra, O. M. Febriani, And B. Bachry, "Implementasi Genetic Fuzzy System Untuk Mengidentifikasi Hasil Curian Kendaraan Bermotor Di Polda Lampung," J. Sist. Inf. Dan Manaj. Basis Data, Vol. 1, No. 1, Pp. 21-30, 2018.

[3] O. M. Febriani And A. S. Putra, "Sistem Informasi Monitoring Inventori Barang Pada Balai Riset Standardisasi Industri Bandar Lampung," J. Inform., Vol. 13, No. 1, Pp. 90-98, 2014.

[4] Putra, Arie Setya. "2018 Artikel Struktur Data, Audit Dan Jaringan Komputer." (2018).

[5] Putra, A. S. (2018, July 17). Paperplain Fundamental Create Application With Borland Delphi 7.0 University Of Mitra Indonesia. Retrieved From Osf.Io/Pbrn9.

\section{E. REFERENCE(Based APA )}

Putra, A. S., Aryanti, D. R., \& Hartati, I. (2018, November). Metode SAW (Simple Additive Weighting) sebagai Sistem Pendukung Keputusan Guru Berprestasi (Studi Kasus: SMK Global Surya). In Prosiding Seminar Nasional Darmajaya (Vol. 1, No. 1, pp. 85-97).

Sari, D. P., Febriani, O. M., \& Putra, A. S. (2018, November). Perancangan Sistem Informasi SDM Berprestasi pada SD Global Surya. In Prosiding Seminar Nasional Darmajaya (Vol. 1, No. 1, pp. 289-294).

Putra, A. S. (2018). Paperplain: Execution Fundamental Create Application With Borland Delphi 7.0 University Of Mitra Indonesia.

Putra, A. S., Sukri, H., \& Zuhri, K. Sistem Monitoring Realtime Jaringan Irigasi Desa (JIDES) Dengan Konsep Jaringan Sensor Nirkabel. IJEIS (Indonesian Journal of Electronics and Instrumentation Systems), 8(2), 221232.

Darmawan, A., Yuliawati, D., Marcella, O., \& Firmandala, R. (2016). Sistem Absensi dan Pelaporan Berbasis Fingerprint dan SMS Gateway. EXPLORE, 7(1).

Febriani, O. M., Wahyuni, T., \& Yusuf, S. (2017). DESIGN OF WEBSITE-BASED INFORMATION SYSTEM FOR EDOCUMENT ADMINISTRASI IN THE COMMUNITY SERVICE UNIT (A Case Study at Rajabasa District). INTERNATIONAL JOURNAL OF 
COMPUTERS \& TECHNOLOGY, 16(7), 7010-7020.

Febriani, O. M., \& Wahyuni, T. (2017, October). PERANCANGAN SISTEM E-DOCUMENT ADMINISTRASI LOGBOOK PENELITIAN PADA UNIT LAYANAN DI BANDAR LAMPUNG. In Prosiding Seminar Nasional Darmajaya (Vol. 1, No. 1, pp. 187-194).

Febriani, O. M., \& Permadi, A. B. (2017). Implementasi Sistem Aplikasi Data Bimbingan dan Pelanggaran Siswa pada Sekolah Menengah Atas di Lampung Tengah dengan Metode Analisis dan Desain Sistem Terdistribusi (SSAD). EXPERT, 7(1).

Febriani, O. M., \& Ambarwati, L. (2015). PERANCANGAN APLIKASI PENGOLAHAN DATA PENJUALAN UKM KELANTING KHAS TELO DESA SIDOHARJO KECAMATAN JATI AGUNG KABUPATEN LAMPUNG SELATAN. Jurnal Teknologi Informasi dan Bisnis Pengabdian Masyarakat Darmajaya, 1(1), 77-95.

Febriani, O. M. (2015). Rancang Bangun Aplikasi Ecommercemenggunakan Freewebstore pada UKM Kelanting di Desa Sidoharjo Lampung Selatan. Prosiding Sembistek 2014, 1(02), 446-458. 